\title{
PSYCHOLOGICAL APPROACHES TO THE SONG OF SONGS
}

\author{
Pieter van der Zwan ${ }^{1}$ \\ Post-doctoral research fellow \\ University of Pretoria \\ E-mail: pvdz1811@gmail.com
}

(Received 30/01/2016; accepted 24/10/2016)

\begin{abstract}
Within the broader psychological biblical criticism this study intends to motivate why psychological approaches to the text of the Song of Songs make sense for a meaningful reception, which kinds of psychological approaches suit this analysis the most, and how they could be utilised for analysing and interpreting the characters that feature in this lyric love poetry, with a special focus on the unconscious way they perceive their bodies and those of others.
\end{abstract}

\section{INTRODUCTION}

The psychological perspective to the Song of Songs (the Song) stems directly from the psychological perspective to the Hebrew Bible which includes both psychology of literature and psychology of religion. The focus here will be on the Song as literature (with religious elements) and more specifically on the characters and how they view their bodies and those of others, that is, their "body psychology". This study therefore hopes to serve as a preparatory and inviting hermeneutic for a psychoanalytic study of the body in the Song from the viewpoints of its different characters.

After outlining the context within which psychological criticism arose, the rationale of this hermeneutic for the Song and the suitability of some approaches from depth psychology to it will be explained in order to finally highlight some practical ways to analyse and interpret the Song from a psychological perspective. This limitation stems from the way the unconscious functions in respect of the Song and

1 This article forms part of a post-doctoral programme enabled by the NRF for which the author is extremely grateful. It was presented as a shorter paper during the 3rd Song of Songs Symposium on 4 July 2014 in Vienna. 
from the multiplicity of psychological approaches which cannot be dealt with within this brief study.

\section{CONTEXT WITHIN WHICH THE PSYCHOLOGICAL APPROACHES AROSE}

Psychological interpretations of biblical texts have always at least indirectly been made, especially when exegetes tried to retrieve the "original" meaning of the text, that is, the intention of the author(s).

Before the modern age the link between these two study fields reaches back to early ecclesiastical dialogues with Stoic philosophy, with Plato, and with Aristotle, by individuals such as Tertullian, Augustine, Cassiodorus, and Melanchton (who in 1530 first used the word "psychology" in academia). In the sixteenth century psychology, angelology and demonology were three sub-disciplines of pneumatology and therefore of theology. A little later psychology and somatology merged to form the new discipline of Anthropology (Kille 2001:1). Between 1769 and 1848 the link between psychology and religion was explored by, amongst others, Magnus Roos, Johann Tobias Beck, and J.G.F. Hausmann. The Old Testament scholar, Franz Delitzsch, carried the interest between psychology and religion further in System der biblischen Psychologie (1855) (Rollins 1996:161). In 1913 Carl Gustav Jung pleaded that different fields of study, such as religion, be linked to psychology. In the same year, however, Albert Schweitzer published The psychiatric study of Jesus: exposition and criticism, as an attack on such a link. Despite the significant impact this publication by Schweitzer had, numerous psychoanalysts such as Karl Abraham, Otto Rank Ernst Jones, Jacques Levy, Theodor Reik, Bruno Bettelheim, Karl-Albrecht von Groddeck, Géza Róheim, Carl Jung, Oskar Pfister and Marie Bonaparte, as well as some scholars in the history of religion school and other fields continued to reflect on psychological interpretations of the Bible (see Lang 1995:49). In 1969 Frederick C. Grant wrote an essay reviving the call for a depth-psychological interpretation. His essay was initially mostly ignored, but then filtered through various critiques of historical and literary 
criticisms, on the one hand, and the depth-psychological culture which had been gaining momentum, on the other, first affecting theologians before Bible scholars (Rollins 1999:340). In 1991 psychological criticism was included in the annual programme of the Society of Biblical Literature, and since 1993 Biblical Interpretation: a Journal of Contemporary Approaches has reached out to other disciplines, including to Psychology, to enrich itself in this way. In the same year Psychology was also included in a document of the Pontifical Biblical Commission (Rollins 1995:11-12).

After more than a century of historical criticism in its various methods, such as textual, source, form and redaction criticism, leading to often contradictory findings, the rise of psychological criticism in the late 1960s started as a critique of this traditional methodology, sometimes expressing bitterness and even aggression against the latter's seemingly futile, pretentious and misplaced nature. These sentiments are clear from such biting statements by Eugen Drewermann (1984:13), one of the two main European exponents of psychological biblical criticism (along with Gerd Theissen), when he regards historical exegesis as "Heuchelei und Mummenschanz" (hypocrisy and masquerading) "in theologischer Verkleidung" (in theological disguise). He insists on penetrating to the inner meaning of religious texts, in opposition to the historical background, which he considers as external form only (Drewermann 1985:671).

Two additional developments in psychology have of late contributed to a greater interest in biblical interpretation: a wider perspective than the individual within psychology, and the insight that even psychologies, especially depth-psychologies, are themselves hermeneutical systems (Kille 2001:7-8).

\section{RATIONALE FOR APPLYING PSYCHOLOGICAL APPROACHES TO THE SONG}

Interdisciplinary work, such as a psychological approach to biblical studies, is not necessarily supported by the respective disciplines drawn on, and often leaves one at the margins of both, perhaps adumbrating the fragile position of the two lovers in the 
Song. However, risking such an enterprise promises to widen the horizons and rewards one with a more holistic and more meaningful result. Just as psychological research has shown that, generally, a more positive approach to life leads to a more holistic view, the inverse might also be hoped for: that a more holistic approach would also render reception of a particular text a more positive experience.

Analysing and interpreting the Song's characters as case studies will render them more alive. This is akin to the associations from the unconscious which Freud used, and to the conscious amplification which Jung recommended in the sense that the characters are "written further" than the letter of the text, just as the historical-critical methods widen the visible background in which the text is embedded. Different from the suggestions by these two above-mentioned leaders in psychology who prompted a subjective expression of the mind of the recipient of the Bible text, scientifically, that is, "objectively", unpacking the details yielded by the text should be similar to a forensic investigation, where a limited amount of data is supplied by a third party. This information should then lead to the same results, independent from who the researcher is, although as scientific findings the results naturally always remain temporary. In this way the implied personality traits of a character from a Bible text can add depth to that character and facilitate a greater potential to relate to it.

Just as historical criticism consists of various methods, different avenues could be followed by a psychological perspective: the American Psychological Association currently has 54 divisions, each with their own subdivisions, and sometimes rendering contradictory research findings. Psychological approaches can therefore sometimes seem terribly diffuse. Yet they have been used in feminist, ideological, deconstructionist, reception and structuralist critiques; in fact, all critical methods have psychological dimensions, which a psychological approach can make explicit.

This study focuses, however, on approaches from depth psychology, i.e., on the psychoanalytic (Freudian) approach (e.g., Freud 1905); the analytical (Jungian) approach (e.g., Jung 1978); and transpersonal-psychological approaches such as the collective approach of Wilber (Wilber 1995), and the individual approach of Washburn (Washburn 1994). 
The authors of a text (the world behind the text), the characters (the world of the text) and the recipients (the world in front of the text) can all be valid objects of psychological analysis and interpretation (Rashkow 1999:335). Freud already applied his methods to literary texts, including the Hebrew Bible, and even other cultural artefacts, while Jung referred to no other world literature as many times as to the Bible, including references to the Song. The relationship between literature and psychodynamic psychology has thus always been a close one. A focus on the author(s) will become a historical study again, with all the caveats and risks which it entails. Kille (2001:141) is likewise critical of psychological approaches to what lies behind the text. A focus on the reception of the Song might have to involve empirical research and different results from different recipients. A focus on the characters as they appear in the text, however, will be phenomenological, as they seem to be independent of history or reception, but this will be deceptive, as one could still ask how the author(s) intended them to appear in the text despite their appearance as independent of this intention. One could still retort that the intention of the author(s) is irrelevant, as a product is always more than and different from the conscious intention of its creator and that characters acquire a life of their own, independent of the author(s) (Jung 1966:71). The text is, however, not neutral and is always determined by its reception. This is especially true for the interpretation of the Song, which has probably had more diverse commentaries written on it than on any other biblical book.

Miller (2012:113) claims that studies of the text-as-an-object rely on literary criticism. That the psychological approaches to the Song are grounded in literary criticism already flows from the psychological functions which figures of speech play when used in its poetry. Metaphors are considered by Freud as displacement and metonyms as condensation, overdeterminations as they also occur in dreams, which could be expressed in, for instance, the pseudo-narratives of 3:1-4 and 5:2-7, two passages which, however, remain without context in that no explanation is given as to how these events came about. The whole Song could, of course, also be understood as a dream or at least dream-like in speaking about inner experiences. This is perhaps why Drewermann in his voluminous work hardly refers to the Song: perhaps he 
regards the Song as already a psychological report which cannot be further "psychoanalysed", because nothing much happens in the narrative.

The content of the dense and intense lyrical poetry of the Song includes physical sensations and emotions, and it is therefore an invitation to experience, rather than a message (cf. Miller 1995:103), a benefit perhaps for pastoral care (Harsch 1972:32). Apart from expressed feelings, there is very little content in the Song. Even what seems to be the first second-order discursive reflection in the third person, as if it presents a metaphysics of love in 8:6b-c, is actually an emotional crescendo after all

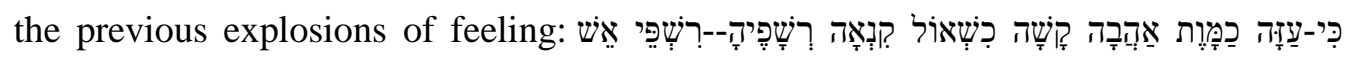

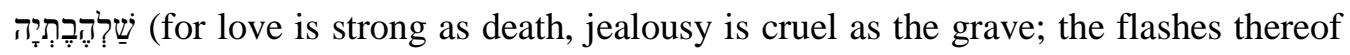
are flashes of fire, a very intense flame). Lang (1995:33) regards this as something rooted in romanticism: the poet does not believe but loves. He refers in this respect to the American sociologist Philip Rieff: the modern, "psychological" person is looking mainly for therapeutic wisdom and experience in holy scriptures of various traditions. Even in their scathing critique of Drewermann, Lohfink and Pesch (1987:102) acknowledge that the shift towards the psychological interpretation of the Bible is due to the lack of a living experience in the faith community. Amongst all the hermeneutical approaches, the psychological perspective is probably most suitable to assist the recipient to identify and understand characters within a text. Different from narrative and drama approaches, which both reflect or imitate external reality or a third party, lyric mimics the internal life of usually a single voice which induces these inner experiences in the recipient, who participates empathically with the thoughts and feelings thus induced. Whereas drama and narrative show social relationships and thus function more in a sociological way, lyric interacts more individualistically with the reader or listener, and therefore works more psychologically (Linafelt 2006:292).

This study, however, focuses more on the psychological understanding of characters within the poem. From a Jungian perspective, the characters in the Song are different parts of the self which struggle towards integration, towards a fuller self. This stretching or widening of the self can be assisted through amplification, by finding parallels in mythology and symbols of other cultures. The river or stream in 5:12, for 
instance, can be an archetype of transformation. As narrative about the awakening nature of sexuality, it can also be interpreted as the awakening of the self to itself, as the unconscious is a discovery made only during adolescence (Selman 1982:389).

For Jung this individuation constitutes a positive experience of God. This view would, however, reflect implicitly on the author who is expressed through the character as projections, or even on the recipient, but not on the characters as separate individuals.

The architecture of the text can also be studied from a psychological angle. The circularity and spiral character of the Song (Fischer 2010:passim) suggests a kind of dream-labyrinth. It can suggest a continuous re-reading, and can function as a wholeness symbol towards the integration not only of opposite gender parts within the psyche, but also of other shadows, such as friction (Fischer 2009:passim; Fischer 2014:passim), anxiety, pathology and perhaps even violence - aspects which are not normally acknowledged in this poem. Psychoanalytic text-hermeneutics, on the other hand, is acutely aware of tensions, logical discrepancies and other inconsistencies, and can consequently clarify the fragmented nature of the Song's text by taking into account unconscious factors (Oeming 1995:108).

Just as is the case with literary analyses, psychological approaches explore the text synchronically and, in that sense too, could be accused of imposing modern thought categories onto an ancient text, which would amount to anachronistic interpretation. However, as Clines (1995:103) remarks, one should not be kept captive by the norms or even categories of a text, but should have the freedom to evaluate and interpret it from the present recipient's own standards, in order to be an authentic reading. This is not eisegesis, but a merging of horizons and a critical stance towards the original message or intention of the text, to the extent that these can be pinned down.

\section{SOME PSYCHOLOGICAL APPROACHES TO THE SONG}

That the Song has enjoyed an exceptional recognition amongst the great mystics (Feuillet 1990:217) is thanks to its high degree of psychological symbolism (Edinger 
1995:252) as can be gathered from the cabbalistic and alchemistic processing of the text. That means that the use of a psychological hermeneutic was actually motivated by the religiosity recognised in the Song.

Harsch \& Vos (1972:41) advocate an approach from depth psychology and specifically its focus on archetypes as suitable for texts with mythological elements, which Freud, however, regarded as symptoms of illness. Jung, who believed that contact with the archetypes imparts life force, and that cultures which lose this disintegrate and die out, considered the mythological background of the Song's lovers in the love and maternal deities incarnated and hidden in various elements of nature (Jung 1978a:34-35). This led him to see the female lover as the superlative form of the four presentations of the anima archetype (Jung 1978b:195). This was a further development from the earlier approach from the history of religions, where the parallels with deities in the Near East had been noticed already.

In 1970 Günter Krinetzki (1970:404-416) introduced a Jungian approach to the Song, and included the contributions of Erich Neumann on the feminine archetype manifested in the Great Mother, above all expressed in אַדָרָה (love) with which the female beloved is identified. This work culminated in a whole psychological commentary on the Song in 1981. Krinetzki limits himself, however, mostly to identifying and analysing the animus and the anima in the Song, and one often gets the impression that one is not reading about real lovers but about solipsistic parts of the self. Krinetzki (1981:198) also seems to oppose any literal understanding of the Song, denying historical influences and claiming that almost everything mentioned in the Song is a reference to something else, for example, the lilies stand for the erotic. This obviously reminds of the allegorical interpretations: the exaggeration of psychological biblical criticism could indeed lead to a "Psychoallegorese" (psychological allegorical interpretation; Bucher 1992:84). In fact, depth psychological interpretations are also sometimes regarded as an allegorical method of interpretation (Viviers 1982:110).

A similar perspective has also been used by van der Zwan (2012:passim) when identifying different transpersonal psychological layers in the Song. Tendencies of an oral-narcissistic-depressed personality of the female character in the Song have 
subsequently been identified by him as well (van der Zwan 2014:2ff.). This already steers away from tying the application of a psychological approach to any religiosity, which is explicitly absent in the Song, despite it recognition on an implicit level (van der Zwan 2012:passim).

Rollins, who has been most involved with analysing the Bible from a psychological perspective, focuses on archetypes, the narrative and its discourses and character analysis (Kille 2001:14). Apart from analysing more archetypes such as that of the trickster, the damsel in distress and even rebirth in the Song, Rollins also mentions numbers, colours, body parts, animals and nature in general as typical elements in a text which make it available for analytical psychology. These are all features which occur frequently in the highly sensual Song. That the search for archetypes implies a common humanity with which the recipient can resonate, sounds appealing, but that these archetypes transcend history could be understood to be in opposition to historical criticism and also to be going against the grain of postmodernism, which critiques and denies any claims to universality as modernistic myths.

Freudian psychology seems to have been neglected in respect to the Song, despite its strong emphasis on the "crisis" of love with all its sexual undertones. Lang (1995:53-54) distinguishes the psychology of Freud, with its Jewish background, as more suitable for the Bible which has been written from a more patriarchal frame of mind, from Jungian psychology which has been applied more to matriarchal fairy tales, although Jung often referred to the Bible which he regarded as expressions of the (feminine) soul. In opposition to Freud and his successors, however, Jung evaluated the unconscious, religion and the Bible positively (Rollins 1996:154-156).

Yet psychological criticism of the Song remains in its infancy. Someone as prominent in the psychological interpretation of the Bible as Drewermann devotes only a paragraph to the Song in his 750-page second volume of Tiefenpsychologie und Exegese (1985:217-218), and then only to illuminate what he believes is the psychosomatic experience of the beloved in 5:2 and 5:5. Moreover, psychological approaches to the Bible seem to favour narrative rather than lyrical texts. The dialogue 
in the Song and its few narrative traces provide, however, ample data for such a psychological understanding of the characters. ${ }^{2}$ This is similar to psychotherapy which is based solely on the words of the patient who does not act out much explicitly.

\section{PRACTICAL WAYS TO ANALYSE AND INTERPRET THE SONG}

By analysing the Song's characters as personalities, especially as they reveal themselves in dialogue, the question about the uniqueness of the poem might be answered. Although similar imagery as that used in the Song has been found in parallel texts from Egypt and Mesopotamia, new perspectives are offered in the Song by the different characters in dialogue.

The results from a psychological approach to the Song will logically be determined by whether the poem is taken literally or allegorically and therefore as a religious text in the latter case. When a character is understood as God dressed up as a lover, openness to discover any less divine personality from the textual data will naturally be constrained, because of personal religiosity or at least respect. God is not available as a personality in the mind of the interpreter and the characters as his mask is the only presentation which is available for human psychology. Accepting, however, that the text is not an explicitly religious text would free the psychological hermeneutic from any tension between religion and psychology. That would not deny

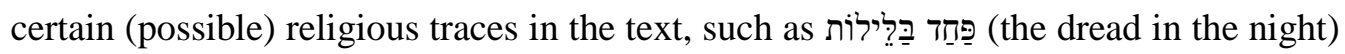
in 3:8 referring perhaps to demons, but would include them as significant for the interpretation of a character's personality and views.

In outlining a character, what is unsaid but can be read between the lines should also be taken into account. What is silenced can be regarded as the unconscious of the character, if not of the author. The words of the Song are the conscious expression of something unconscious. Depth-psychological approaches are not only looking for that "origin" behind or below the text, but also in the text.

2 There are not only the two (or three, depending on one's interpretation) lovers. 
This openness of the text is, however, limited. David Clines (1995:104-106) probably exaggerates when he claims that the female lover in the Song is so open and so loving because she never existed; she is nothing but the figment of the male author's wish-fulfilling imagination; he dreams of a woman dreaming of him. Although Clines wants to suggest the openness of fantasy expressed in the Song, he might in effect be closing the text by denying the woman her reality, just as the allegorical interpretations he critiques have done when they re-interpreted her as either the church or God or anyone who is not a woman (Clines 1995:113).

Linefelt (2006:297) likewise regards the actors in the Song as voices rather than characters, with the latter normally absent in lyrical poetry. The dialogue in the Song would then reveal relationality and feelings rather than characters, as there is also very little internal plot or character development such as peripateia (reversal of fortune) and anagnorisis (a dramatic moment of recognition or truth) which is so typical of narrative characterisation, except perhaps in the two seemingly narrative sections of 3:1-4 and 5:2-7. Even if the term "character" is not strictly speaking applicable here, there seems however to be enough information to outline a personality from the dotted fragments in the text - perhaps a challenging exercise due to the multiplicity of variables, but hopefully promising more rewards than refraining from the risk.

Although the female lover, being the character who appears most in the poem, remains anonymous despite the enclitic reference to her as (the Shulammite) in $7: 1$, a psychodynamic perspective could deal with a certain measure of probability with reconstructing her personality and experiences: how is it possible that a lover never addresses his beloved by her name, which one would expect to be associated with her love and her beauty, and therefore be sweet? Neither is a father ever mentioned in the Song, not even in memory, if he has passed away, and the female lover's relationship to her brothers, or, as she calls them, רִִִִּּ (the sons of my mother) in 1:6, feels strained. She is called אָזוֹ (sister) in 8:8, but she never calls anyone explicitly אָָ (brother), except her lover in 8:1 with whom she wishes to be one. From her repeated mentioning of (dạ (my mother), her relationship with women is clearly asymmetrical to that with males. A depth- 
psychological approach could assist in answering such questions as whether the female lover has particular oedipal struggles, especially as she never refers to sisters either. What role models function as constraining superego in the Song, and what psychological defences are mustered against anxieties?

The brothers as passively mentioned in 1:6, but also as actively participating voices in 8:8, will add much to interpretations about the social, gender and family relations referred to in the female voice. Depth-psychology is namely particularly interested in the individual's internal dynamics about external relationships.

From such psychoanalytic character studies, a more specific focus can follow on the way they view their bodies and those of others. The Song excels in its references to the body, and as possible epithalamium it contains four aușâf (bodily descriptions): one of the male in 5:10-16, and three of the female lover in 4:1-7, 6:4-7, and 7:2-8. Freud (1949:31) regarded the ego as a body-ego in the first place, and from this perspective such an investigation will be an important step towards a more holistic study of the characters from a psychoanalytic perspective. As the conscious can never perceive the body as a unit (Gallagher \& Cole 1998:135; cf. also Bester 2007:38n.230), the question about the underlying image of the body in the unconscious can be addressed by a psychoanalytic analysis of the "fragmented" bodies (in the sense of body parts only) as presented in the Song.

Of course, the cultural background of the text must be taken into account in order to interpret this correctly, and then historical criticism is pertinent. As for the male lover, his identity is ever more obscure, to the extent that some have recognised two different male lovers. His association with Solomon is an indirect one and remains open for interpretation. More latent information remains with less prominent

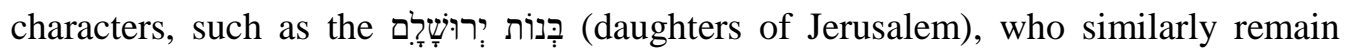
anonymous.

These "gaps" in the text constitute one of the factors which have left it as an open text, inviting the projections of the recipient to be mirrored, but also inviting the continuous, creative co-writing of the text as Roland Barthes (1973:passim) idealised it. Yet, a more scientific psychological approach which analyses the hidden parts of 
characters will render the text again lisible ("readerly") instead of his preferred scriptable ("writerly") and in that way seems to "close" the text again. However, the active, critical participation process of engaging from a psychodynamic perspective with the characters still challenges the recipient, who will be rewarded with Barthes' promised jouissance (orgasmic bliss - quite relevant for the Song!), especially if it constantly criticised and corrected by other scientists.

\section{CONCLUSION}

Psychological criticism is an acknowledged approach to literature, irrespective of whether the content of the literature is religious or not. As the Song has been interpreted as literal and literature in modernity and postmodernity, the use of psychological approaches should be evident. Psychological approaches can assist to experience the Song as they appeal to the recipient's internal processing of this lyrical poetry. Yet the plethora of psychological approaches to the Bible with sometimes contradicting or seemingly pseudo-scientific results has rendered this perspective suspect of the same crisis as historical criticism, which had seemingly entrapped research on the Song during the last century, and could suggest that interpretation has regressed from the historical to the hysterical. With the focus on the analysis of the characters in the poem, which makes them more vivid and more prominently present, new experiences for the recipient can be opened up, including a sense of relationship with them. The benefit of any psychological approach is, however, that secondary thought processes about the hermeneutical circle should follow, so that the process of self-reflection as check on the sensitivity of the interpreter always remains open and encourages the necessary humility. This can at least partially be achieved by remaining in a dialectical dialogue with all other perspectives. Just as no discipline can afford to function on its own or in a reductionist way in the postmodern world, psychological criticism of the Song should be complementary and in tandem with other approaches. 


\section{BIBLIOGRAPHY}

Barthes, R 1973. Le Plaisir du Texte. Paris: Éditions du Seuil.

Bennett, L et al. (eds) 1996. Biblical and humane: a festschrift for John F. Priest. Atlanta:

Scholars Press.

Bester, D 2007. Körperbilder in den Psalmen. Studien zu Psalm 22 und Verwandten Texten. Tübingen: Mohr Siebeck.

Bucher, A A1992. Bibel-Psychologie: psychologische Zugänge zu biblischen Texten. Stuttgart:

Kohlhammer.

Burrus, V and Keller, C (eds) 2006. Toward a theology of Eros: transfiguring passion at the limits of discipline. New York: Fordham.

Clines, D J A1995. Interested parties: the ideology of writers and readers of the Hebrew Bible. Sheffield: Academic Press.

Delitzsch, F1855. System der biblischen Psychologie. Leipzig: Dörffling \& Franke.

Drewermann, E1984. Tiefenpsychologie und Exegese. Band 1: Die Wahrheit der Formen: Traum, Mythos, Märchen, Sage und Legende. Freiburg in Breisgau: Olten.

1985. Tiefenpsychologie und Exegese. Band 2: Die Wahrheit der Werke und der Worte: Wunder, Vision, Weissagung,Apokalypse, Geschichte, Gleichnis. Freiburg in Breisgau: Olten.

Edelstein, W and Keller, M (eds) 1982. Perspektivität und Interpretation: Beiträge zur Entwicklung des sozialen Verstehens. Frankfurt am Main: Suhrkamp.

Edinger, E F 1995. The mysterium lectures: a journey through CJ Jung's mysterium coniunctionis. Toronto: Inner City.

Feuillet, A 1990. Perspectives nouvelles à propos de l'interprétation du Cantiques des cantiques. Les formules de possession mutuelle de 2 : 16; 6:3-4; 7:11, Divinitas 34/3:203-219.

Fischer, S 2009. Machtstrukturen der Gewalt in Hoheslied, Protokolle zur Bibel, 18/2:109-121. 2010. Das Hohelied Salomos zwischen Poesie und Erzählung:Erzähltextanalyse eines poetischen Textes. Tübingen: Mohr Siebeck.

2014. Friction in the fiction of Solomon in Song of Songs, Journal for Semitics 23/2ii:669-682.

Freud, S 1949. The ego and the id. London: Hogarth.

Frye, N 1973. Anatomy of criticism: four essays. Princeton: University Press.

Gallagher, S \& Cole, J 1998. Body image and body schema in a deafferented subject, in Welton 1998:131-147.

Harsch, H \& Voss, G 1972. Versuche mehrdimensionaler Schriftauslegung: Bericht über ein Gespräch. Munich: Chr. Kaiser.

Hayes, J H (ed.) 1999. Dictionary of biblical interpretation. Volume 2. Nashville: Abingdon. Jung, C G 1978a. Antwort auf Hiob. Olten: Walter. 1978b. Man and his symbols. London: Picador. 1996. The spirit in man, art, and literature. London: Routledge \& Kegan Paul.

Kille, D A 2001. Psychological biblical criticism. Minneapolis: Augsburg Fortress.

Krinetzki, G 1970. Die erotische Psychologie des Hohen Liedes, Theologische Quartalschrift 150: 404-416.

1981. Kommentar zum Hohenlied: Bildsprache und theologische Botschaft.

Frankfurt: Lang.

Lang, B 1995. Die Bibel neu entdecken: Drewermann als Leser der Bibel. Munich: Kösel. 
Linafelt, T 2006. Lyrical theology: The Song of Songs and the advantage of poetry, in Burrus and Keller 2006:291-305.

Lohfink, G \& Pesch, R 1987. Tiefenpsychologie und keine Exegese: eine Auseinandersetzung mit Eugen Drewermann. Stuttgart: Katholisches Bibelwerk.

Miller, D L 1995. Afterword: biblical imagery and psychological likeness, in Miller (ed.) 1995:102-112.

Miller, D L (ed.) 1995. Jung and the interpretation of the Bible. New York: Continuum Books, 1995.

Miller II, R D 2012. The Song of Songs: a plea for an aesthetic reading, Sacra

Scripta X/2:113-119.

Oeming, M 1995. Altes Testament und Tiefenpsychologie: Aufklärung oder Freudsche Fehlleistung?, Theologische Literaturzeitung 120/2:107-119.

Rashkow, I N 1999. Psychoanalytic interpretation, in Hayes 1999:335-337.

Rollins, W G 1995. Introduction: psychology, hermeneutics, and the Bible, in Miller (ed.) 1995: 9-39.

1996. Rationale and agenda for a psychological-critical approach, in Bennett et al. 1996:153-172. 1999. Psychology and biblical studies, in Hayes 1999:337-341.

Selman, R L 1982. Entwicklung der Fähigkeit zur Selbstreflexion bei Kindern: Forschungen zum reflexiven Verstehen und die Untersuchung praktischer Verständnisleitungen verhaltensgestörter Kinder, in Edelstein and Keller 1982:375-421.

Van der Zwan, P 2012. The religiosity of the Book of Song of Songs in context. DTh thesis. Pretoria: University of South Africa.

2014. Song of Songs: from transcending to 'transcendental' sex (1), Journal for Semitics 23/2ii:841-861.

Viviers, H 1982. Die struktuur en boodskap van Hooglied. Unpublished BD thesis. Pretoria: University of Pretoria.

Welton, D (ed.) 1998. Body and flesh: a philosophical reader. Oxford: Blackwell. 